\title{
ROMP-Derived cyclooctene-based monolithic polymeric materials reinforced with inorganic nanoparticles for applications in tissue engineering
}

\author{
Franziska Weichelt ${ }^{1}$, Solvig Lenz ${ }^{2}$, Stefanie Tiede ${ }^{2}$, Ingrid Reinhardt ${ }^{1}$, \\ Bernhard Frerich ${ }^{*}, \S$ and Michael R. Buchmeiser ${ }^{*} 3,4, \pi$
}

\section{Full Research Paper}

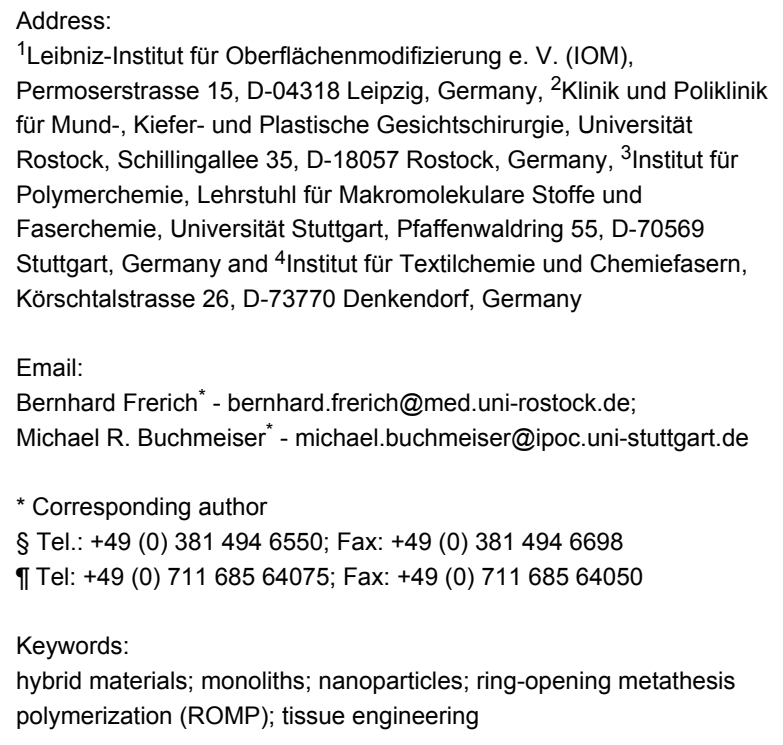

\begin{abstract}
Porous monolithic inorganic/polymeric hybrid materials have been prepared via ring-opening metathesis copolymerization starting from a highly polar monomer, i.e., cis-5-cyclooctene-trans-1,2-diol and a 7-oxanorborn-2-ene-derived cross-linker in the presence of porogenic solvents and two types of inorganic nanoparticles (i.e., $\mathrm{CaCO}_{3}$ and calcium hydroxyapatite, respectively) using the third-generation Grubbs initiator $\mathrm{RuCl}_{2}(\mathrm{Py})_{2}\left(\mathrm{IMesH}_{2}\right)(\mathrm{CHPh})$. The physico-chemical properties of the monolithic materials, such as pore size distribution and microhardness were studied with regard to the nanoparticle type and content. Moreover, the reinforced monoliths were tested for the possible use as scaffold materials in tissue engineering, by carrying out cell cultivation experiments with human adipose tissue-derived stromal cells.
\end{abstract} \begin{abstract}
doi:10.3762/bjoc.6.137
Received: 20 August 2010

Accepted: 12 November 2010

Published: 17 December 2010

Guest Editor: K. Grela
\end{abstract}

Beilstein J. Org. Chem. 2010, 6, 1199-1205

(c) 2010 Weichelt et al; licensee Beilstein-Institut. License and terms: see end of document. 


\section{Introduction}

Tissue engineering (TE), a sub-area of regenerative medicine, brings together diverse technologies and interdisciplinary fields such as biology, engineering, material and life sciences, polymer and inorganic chemistry [1-3]. Its general task is the development of functional substitutes for the replacement or restoration of tissue or organ function with scaffolds containing specific populations of living cells [4,5]. After the cultivation of cells on such biological substitutes, they are subsequently applied to living organisms, where they ideally should restore, maintain or improve tissue function or whole organs [2,3]. A challenging task in this context is the development of suitable scaffold materials, which can act as matrices for the delivery of the cells to defect sites, with desired properties such as adequate pore size and pore structure, biocompatibility, biodegradability or mechanical strength.

Due to their unitary porous structure and the ease of synthesis via polymerization or consolidation processes, monolithic materials were introduced into the field of TE some years ago $[6,7]$. Several studies have shown that the properties of the scaffold material, such as mechanical properties, porosity or surface structure, strongly affect the differentiation of mesenchymal stem cells (i.e., the formation of osseous, muscle or neural cells) and especially for the differentiation into osteoblasts, stiff materials are required [7-12]. Bone is a natural composite material, being composed of an inorganic compound (calcium hydroxyapatite) incorporated into an organic matrix (collagen) and thus resulting in a material, which possesses high stiffness and fracture toughness $[13,14]$.

Ring-opening metathesis polymerization (ROMP) derived norborn-2-ene (NBE)-based monolithic materials have previously been successfully tested for both osseous and adipose cell growth [6]. However, it has also been reported that the mechanical properties, such as hardness, of such scaffold materials were quite low. Harder materials with a specific surface structure and porosity, however, would allow for the differentiation of mesenchymal stem cells into osteoblasts, and thus the development of scaffold materials for bone regeneration. Ideal biomaterials for bone TE should be non-immunogeneic, biodegradable, highly osteoinductive and provide mechanical support when needed [15]. As an alternative to poly(NBE)based monoliths, we investigated the preparation of monolithic structures from a highly polar cyclooctene derivative. So far, ROMP-derived monolithic materials have successfully been applied to separation science as well as heterogeneous catalysis [16-18]. Generally, cyclooctene-derived monoliths differ from their NBE-based counterparts in that they are less prone to oxidation and display higher elastic moduli. With the aim to synthesize organic-inorganic monolithic hybrid materials for application as scaffold materials in TE with specific properties, e.g., high mechanical strength and biocompatibility, we report here ROMP-derived cyclooctene-based monoliths reinforced with two of the most frequently used inorganic materials in nature, i.e., calcite and calcium hydroxyapatite [19], respectively.

\section{Results and Discussion Synthesis of $\mathrm{CaCO}_{3}$ and $\mathrm{HAp}$}

Nanosized calcium carbonate $\left(\mathbf{C a C O}_{\mathbf{3}}\right)$ and calcium hydroxyapatite (HAp) were prepared by precipitation reactions in aqueous solution from $\mathrm{CaCl}_{2} \cdot 2 \mathrm{H}_{2} \mathrm{O}$ and anhydrous $\mathrm{Na}_{2} \mathrm{CO}_{3}$, and from $\mathrm{CaCl}_{2} \cdot \mathrm{H}_{2} \mathrm{O}, \mathrm{H}_{3} \mathrm{PO}_{4}$ and $\mathrm{NH}_{4} \mathrm{OH}$, respectively. For $\mathrm{CaCO}_{3}$, scanning electron microscopic (SEM) images of the powders showed agglomerates of nanoparticles $(\sim 50-100 \mathrm{~nm})$ and a rhombohedral calcite crystal structure was detected both by X-ray diffraction (XRD) and Raman measurements. Nanosized platelets with a thickness $<20 \mathrm{~nm}$ were formed in the synthesis of HAp and exhibited a calcium phosphate hydroxide crystal structure again from XRD and Raman measurements (Figure 1).

\section{Preparation and characterization of mono- lithic materials}

Monolithic hybrid materials were then prepared via ROMP from cis-5-cyclooctene-trans-1,2-diol (COE), a 7-oxanorborn2-ene-derived cross-linker (CL) and up to $12 \mathrm{wt} \%$ of the inorganic compounds in the presence of a microporogen (toluene) and a macroporogen (2-propanol) under phase separation conditions using the third-generation Grubbs initiator $\mathrm{RuCl}_{2}(\mathrm{Py})_{2}\left(\mathrm{IMesH}_{2}\right)(\mathrm{CHPh})\left(\mathrm{IMesH}_{2}=1,3\right.$-dimesitylimidazolin-2-ylidene, Py = pyridine) $($ Scheme 1 , Table 1$)$.

\begin{tabular}{|c|c|c|c|c|}
\hline $\mathrm{CL}^{\mathrm{a}}$ & $\mathrm{COE}^{\mathrm{a}}$ & Toluene $^{a}$ & 2-Propanol ${ }^{\mathrm{a}}$ & Nanoparticles ${ }^{a}$ \\
\hline 22.5 & 22.5 & 9 & 46 & - \\
\hline 26 & 26 & 9 & 33 & $6\left(\mathrm{CaCO}_{3}\right)$ \\
\hline 24 & 24 & 9 & 31 & $12\left(\mathrm{CaCO}_{3}\right)$ \\
\hline 26 & 26 & 9 & 33 & 6 (HAp) \\
\hline 24 & 24 & 9 & 31 & 12 (HAp) \\
\hline
\end{tabular}

$a_{\text {in }}$ wt \%]; $0.07 w t \%$ of initiator were used throughout.

cis-5-Cyclooctene-trans-1,2-diol was chosen as a highly polar monomer, which should together with the 7-oxanorborn-2-enebased cross-linker form a polar polymeric matrix that facilitates the incorporation and homogeneous distribution of the polar nanoparticles. The cross-linker itself has already been reported 
to be biocompatible [7]. SEM images of the nanoparticle-reinforced monolithic materials revealed an increase of the pore sizes with increasing nanoparticle content. An increase of the pore size from 10-30 $\mu \mathrm{m}$ (for monoliths without any inorganic component) up to $25-70 \mu \mathrm{m}$ was observed with the addition of
12 wt $\% \mathrm{CaCO}_{3}$, while pores up to $130-450 \mu \mathrm{m}$ were formed using 12 wt \% nano-sized HAp (Figure 1). Thus, as reported previously [20], the inorganic nanoparticles serve as macroporogens in the phase-separation-triggered synthesis of the monolithic matrix. The adjustment of the pore size by variation

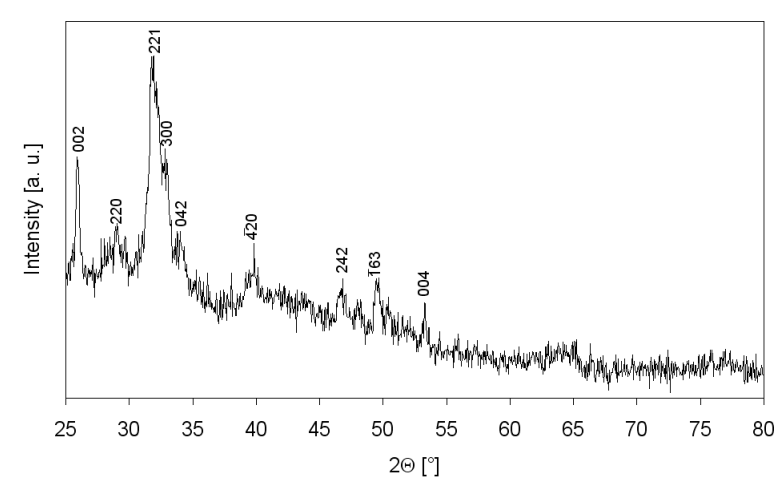

a)

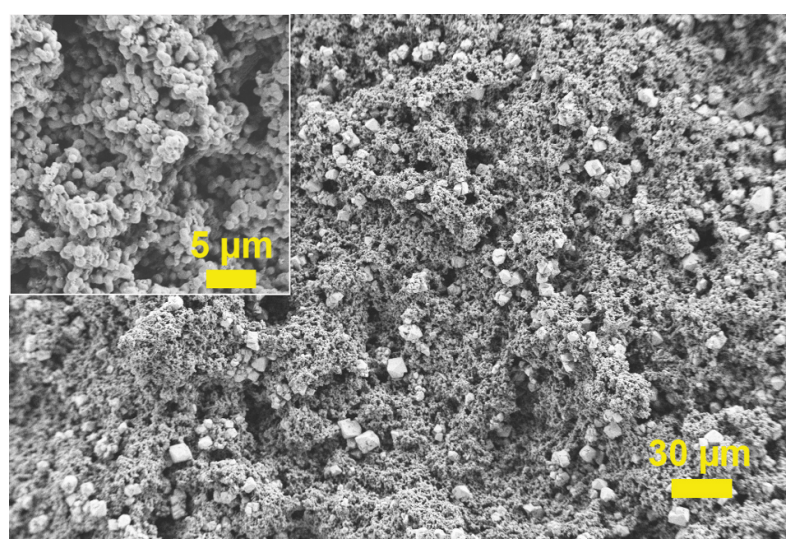

c)

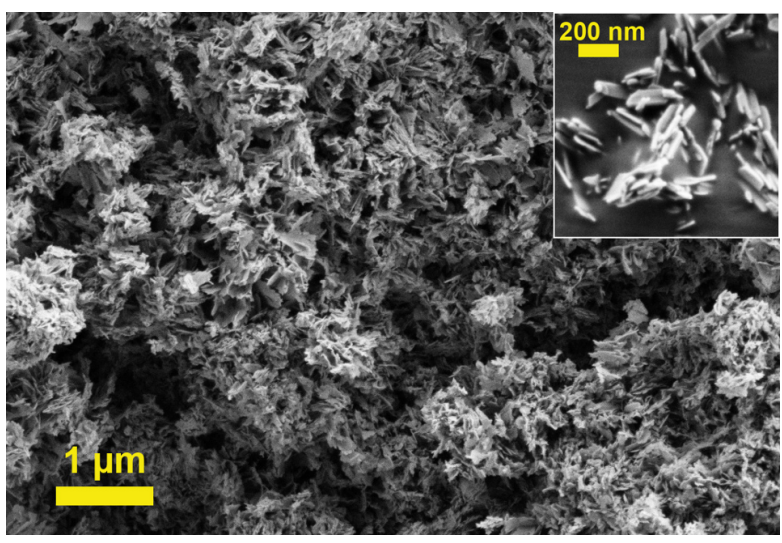

b)

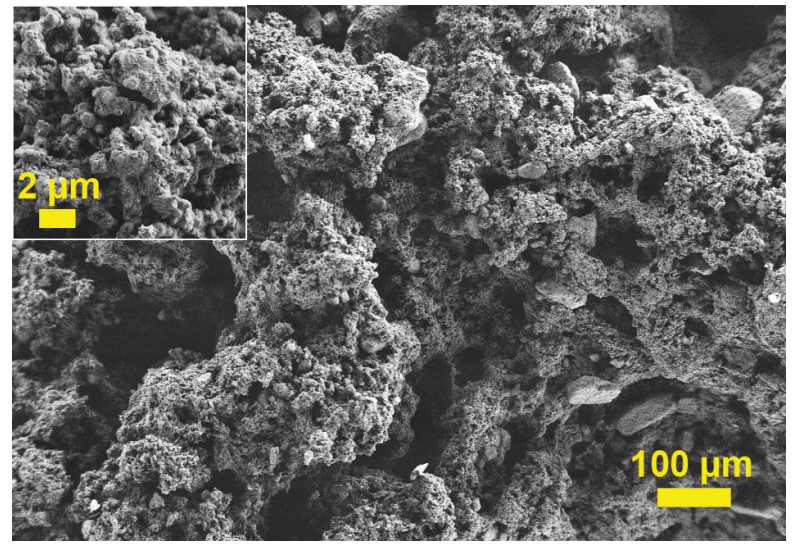

d)

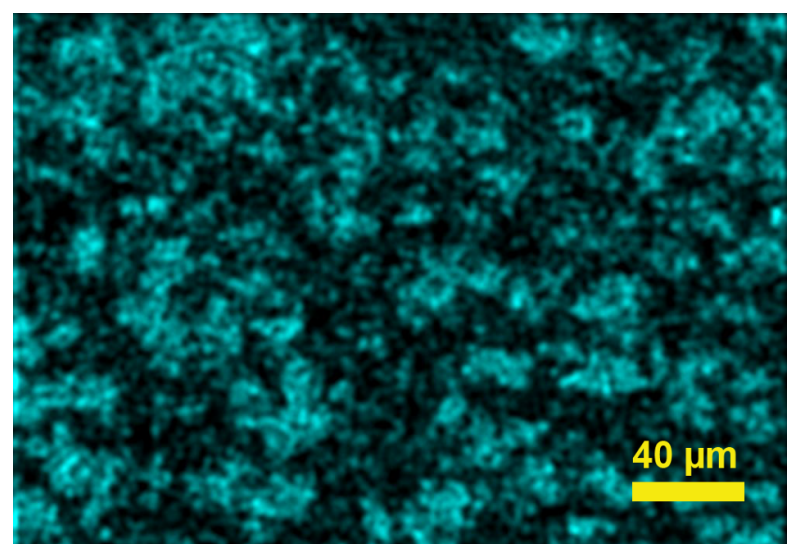

e)

Figure 1: Nanoscale HAp: calcium phosphate hydroxide $\left(\mathrm{Ca}_{5}\left(\mathrm{PO}_{4}\right)_{3} \mathrm{OH}\right)$ as evidenced by XRD measurements (a), SEM picture of the nanoparticles (b), structures of COE-derived monoliths containing $12 \mathrm{wt} \% \mathbf{C a C O}_{3}$ (c) and $12 \mathrm{wt} \% \mathbf{H A p}$ (d), and EDX-measurements of a monolith containing 12 wt \% $\mathrm{CaCO}_{3}$ (Ca-mapping) (e). 


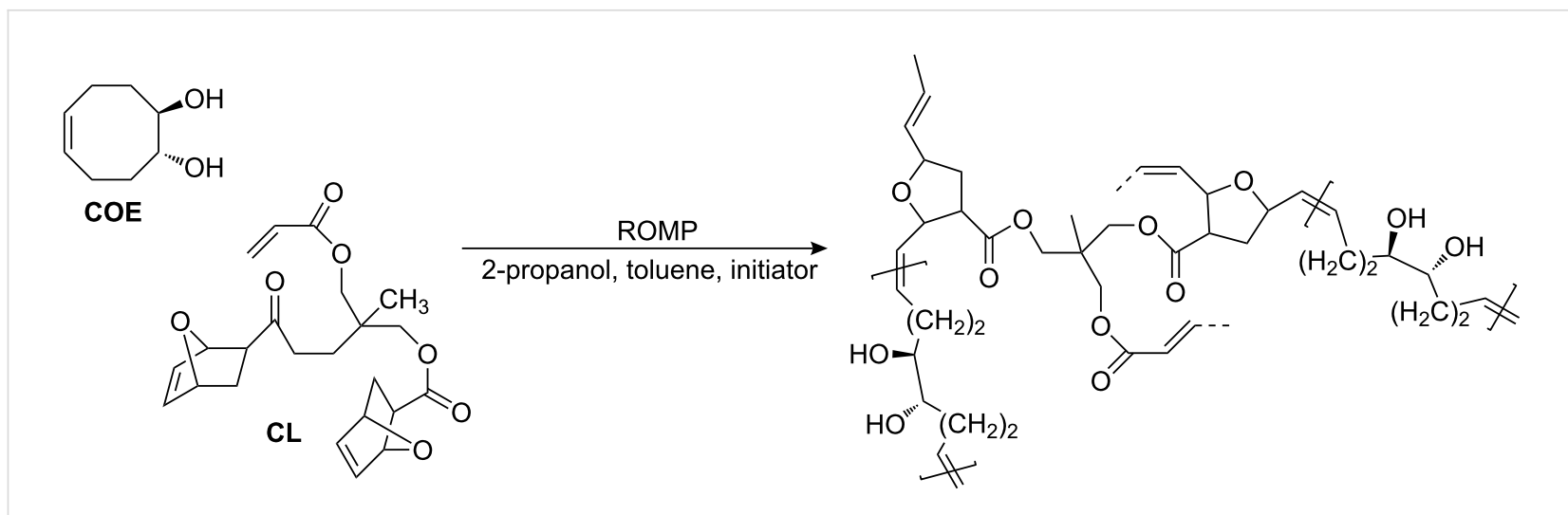

Scheme 1: ROMP-based synthesis of cis-5-cyclooctene-trans-1,2-diol based polymeric monolithic scaffolds.

of the nanoparticle content and type is advantageous and may allow for an alleviated cell attachment as well as ingrowth of living cells on the scaffold materials. Due to the $\mathrm{OH}$ groups present at its surface, $\mathrm{HAp}$ is more polar than $\mathrm{CaCO}_{\mathbf{3}}$ and thus affects the pore formation process more strongly, resulting in even larger pore size. Energy dispersive X-ray mapping (EDX) revealed a homogeneous and non-aggregated distribution of $\mathrm{CaCO}_{3}$ in the polymeric matrix (Figure 1). In contrast, agglomerates of HAp up to $100 \mu \mathrm{m}$ in size were found for HAp-based monoliths and also the distribution of the inorganic compound was less homogeneous, supporting the explanation of polar interactions between organic components and HAp in the polymerization mixture. Nitrogen adsorption measurements of the monolithic powders confirmed their highly porous structure, showing specific surface areas of between $2 \mathrm{~m}^{2} / \mathrm{g}$ (unfilled and $\mathbf{C a C O}_{3}$-reinforced monoliths) and $43 \mathrm{~m}^{2} / \mathrm{g}$ (HAp-reinforced monoliths). The microhardness of the monolithic materials was determined with a Vickers hardness measurement device. In comparison to the microhardness of unfilled COE-based mono- liths $\left(5.8 \mathrm{~N} / \mathrm{mm}^{2}\right)$, a more than 2-fold increase of the microhardness was observed with the addition of $6 \mathrm{wt} \% \mathrm{CaCO}_{3}$ $\left(16.3 \mathrm{~N} / \mathrm{mm}^{2}\right)$ and HAp $\left(12.4 \mathrm{~N} / \mathrm{mm}^{2}\right)$, which decreased with the addition of $12 \mathrm{wt} \% \mathbf{C a C O}_{3}\left(4.5 \mathrm{~N} / \mathrm{mm}^{2}\right)$ and $\mathbf{H A p}$ $\left(8.1 \mathrm{~N} / \mathrm{mm}^{2}\right)$, respectively. The decrease of the microhardness with increasing nanoparticle content is attributed to the increase of pore size and porosity as explained above. Thus, with the addition of inorganic components, the microhardness of COEbased monoliths could efficiently be increased, however, the content of nanoparticles must not be too high, otherwise the effect of the larger pore size and porosity becomes dominant and the microhardness decreases. A decrease of the compressibility, i.e., an increase in the compressive force-compression (CF-C) ratio of $56 \%$ was observed for reinforcement with the addition of $12 \mathrm{wt} \% \mathbf{C a C O}_{3}$ (1.08 MPa for reinforced monolith vs 0.62 MPa for unmodified monolith). Thus, $\mathbf{C a C O}_{3}$-reinforced monoliths were more resistant to the pressure applied. In contrast, a strong reduction of the $\mathrm{CF}-\mathrm{C}$ ratio $(0.03 \mathrm{MPa})$ was observed on reinforcement with 12 wt \% HAp, verifying a high

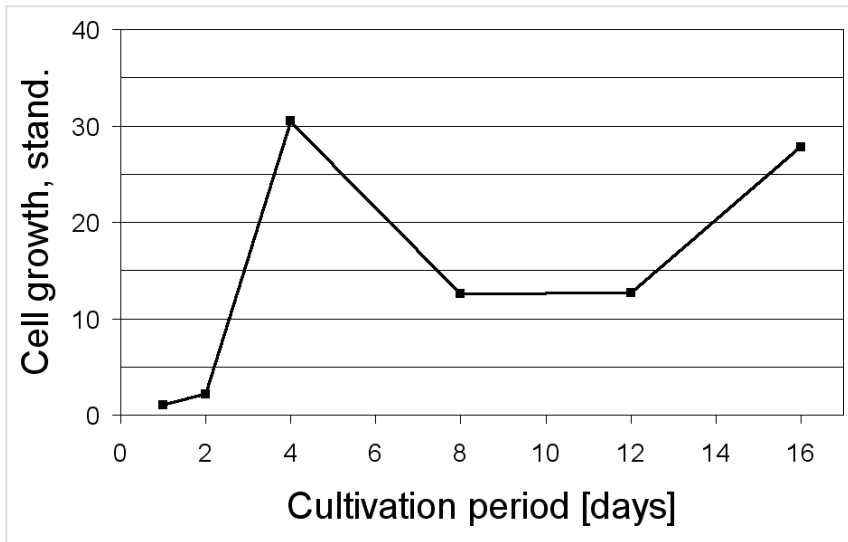

a)
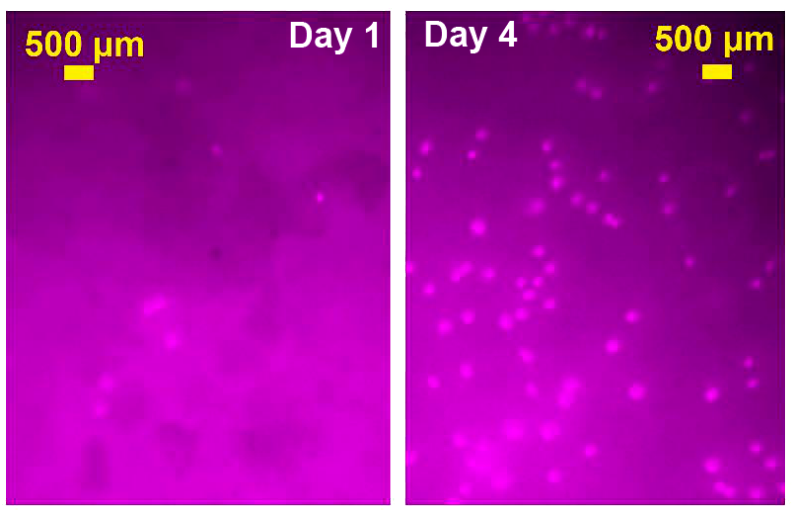

b)

Figure 2: (a) Cell growth of human adipose tissue-derived stromal cells. Each data point is the average of 12 data points. (b) Fluorescence microscopy images of living cells after one and four days of cultivation; cells (human adipose tissue-derived stem cells) grown on a COE-based scaffold reinforced with $12 \mathrm{wt} \% \mathrm{CaCO}_{3}$. 
compressibility of the HAp-based monoliths at simultaneously high microhardness.

\section{Cell cultivation experiments}

After careful washing and drying, the monolithic materials were cut into discs $\sim 1-2 \mathrm{~mm}$ in height and $\sim 10 \mathrm{~mm}$ in diameter and subsequently sterilized via $\gamma$-irradiation. Thereafter, these monolith scaffolds were seeded with human adipose tissuederived stromal cells (hATSCs). Proliferation of the cells was monitored up to the $16^{\text {th }}$ day (Figure 2).

After placing the sterilized discs into 24-well plates, the culture medium was added and the samples were seeded with hATSCs with a density of 20,000 cells $/ \mathrm{cm}^{2}$. Since only a part of the cells settled on the monolithic material, with the other part remaining in the surrounding culture medium, the cell number counted after the first day of cultivation was set as starting value for the proliferation curve. The determined cell numbers of the following days of cultivation were then divided by the starting value, in order to be able to compare the cell growth on different monolithic compositions. As it can be seen, a continuous increase of the cell number was observed up to the fourth day of proliferation, resulting in an increase of the cell number by a factor of $30\left(709\right.$ cells $/ \mathrm{cm}^{2}$ after day 1 vs $21,615 \mathrm{cells} / \mathrm{cm}^{2}$ after day 4). After the fourth day of proliferation the seeded scaffolds were transferred into 6-well plates, which probably affected the cell growth, and explains the decrease of the cell number between the fourth and eighth day of cultivation. Thereafter, proliferation continued with an increase of the cell number after the eighth day of cultivation. These data indicate a good biocompatibility of the monolithic hybrid support as well as sufficient cell adhesion on the monolithic material.

\section{Conclusion}

COE-based monolithic scaffolds have been prepared via ROMP in the presence of two different types of inorganic nanoparticles. It was shown that variation of both the nanoparticle type and content affected the pore size of the monoliths, i.e., the pore size was the larger, the higher the content of the inorganic component. In addition, the mechanical properties of the monolithic structures could be modified with the addition of inorganic components (calcium carbonate and calcium hydroxyapatite, respectively). Preliminary cell cultivation experiments showed that the prepared monolithic hybrid materials can be cultivated with human adipose tissue-derived stromal cells Current work focuses on the biodegradability of the novel scaffolds under physiological conditions.

\section{Experimental}

IR spectra were recorded on a Bruker Vector 22 using ATR technology. Raman spectra were recorded on a Bruker RFS
100. Scanning electron microscopic (SEM) images were obtained on a Zeiss Ultra 55 field-emission (FEG) SEM device (Carl Zeiss SMT, Germany) at $0.6 \mathrm{keV}$ for $\mathbf{C a C O}_{\mathbf{3}}$ and $\mathbf{H A p}$ powders and $1.0 \mathrm{keV}$ for the monoliths. Powder X-ray diffraction (XRD) was performed on a Philips X'Pert wide-angle diffractometer with slit optics, $\mathrm{Cu} \mathrm{K}_{\alpha}$ radiation $(\lambda=154 \mathrm{~nm})$ and $\mathrm{Ni} \mathrm{K}_{\beta}$ filter. The powder was applied to the specimen holder using double faced-adhesive tape and the upper site was covered with a thin layer of the powder. Measurements were carried out at a voltage of $40 \mathrm{kV}$ and a current of $30 \mathrm{~mA}$ in the $2 \Theta$-range of $20-80^{\circ}$ with a step size of 0.05 and 1.00 seconds per step. The microhardness was measured on a Fischerscope H 100 (Helmut Fischer GmbH + Co. KG, Germany). A load of $100 \mathrm{mN}$ was applied on the sample for $20 \mathrm{~s}$. For the determination of the Martens hardness, a Vickers diamond indenter was used. Ten measurements were made to get an average for the sample. A Sonics Vibra-Cell Ultrasonic Processor (Sonics \& Materials, Inc., Newtown, USA) was used for sonication. The compressibility of the monoliths was tested at a Z 1120 zwicki (Zwick/Roell, Germany). The diameter of the specimens was dependent on monomer and nanoparticle content $(\sim 0.8-1.3 \mathrm{~cm})$, the average height was $4 \mathrm{~mm}$. The traverse was applied with a test rate of $1 \mathrm{~mm} / \mathrm{min}$. Due to problems in sample preparation, a perfect sample geometry was difficult to adjust. Hence, it could not be completely excluded that stresses during the compressibility measurements were exclusively induced by the applied pressure of the traverse, but could also arise due to inhomogeneities (porosity, microcracks) within the monoliths. Therefore, the compressibility here was defined as the compressive force-compression ratio ( $\mathrm{CF}-\mathrm{C}$ ratio) applied to the crosssectional area.

$\mathrm{CaCl}_{2} \cdot 2 \mathrm{H}_{2} \mathrm{O}(99 \%)$ and $\mathrm{NH}_{4} \mathrm{OH}$ (aqueous $26 \mathrm{wt} \%$ solution) were obtained from Riedel-de Haën. Anhydrous $\mathrm{Na}_{2} \mathrm{CO}_{3}$ (99\%), anhydrous $\mathrm{Na}_{2} \mathrm{SO}_{4}(99 \%), \mathrm{NaHCO}_{3}(99+\%)$, ethyl vinyl ether (99\%, stabilized), 1,1,1-tris(hydroxymethyl)ethane (97\%) and 2-propanol (99.5\%) were obtained from Acros Organics (Germany). $\mathrm{NaOH}(\geq 98 \%), \mathrm{CH}_{3} \mathrm{OH}(99.8 \%)$ and $\mathrm{H}_{3} \mathrm{PO}_{4}(85 \%)$ were obtained from Fluka (Germany). $\mathrm{CHCl}_{3}(99.8 \%)$, dimethyl sulfoxide (DMSO, 99.9\%), tetrahydrofuran (THF, 99.0\%) and $\mathrm{CH}_{2} \mathrm{Cl}_{2}(\geq 99.8 \%)$ were obtained from Merck. Norborn-2-ene (99\%) was obtained from Aldrich (Germany). Diethyl ether (99.9\%), toluene (technical) and $\mathrm{H}_{2} \mathrm{SO}_{4}(95 \%)$ were obtained from BDH Prolabo (VWR, Germany). The cross-linker (CL) [6,7], cis-5-cyclooctene-trans-1,2-diol (COE) [21] and calcium carbonate $\left(\mathrm{CaCO}_{3}\right)$ [22] were prepared according to literature procedures.

HAp: $\mathrm{CaCl}_{2} \cdot 2 \mathrm{H}_{2} \mathrm{O}(13.26 \mathrm{~g} ; 90.2 \mathrm{mmol})$ was dissolved in 900 $\mathrm{mL}$ of water. $\mathrm{H}_{3} \mathrm{PO}_{4}$ ( $85 \mathrm{wt} \%$ in water; $6.22 \mathrm{~g} ; 53.9 \mathrm{mmol}$ ) was added and the solution heated to $90{ }^{\circ} \mathrm{C}$. $\mathrm{NH}_{4} \mathrm{OH}(26 \mathrm{wt} \%$ in 
water) was added to give a $\mathrm{pH}$ of 9 and a white precipitate formed. The dispersion was cooled to room temperature, the precipitate collected by centrifugation and thoroughly washed with water. Finally, the powder was dried at $100{ }^{\circ} \mathrm{C}$ overnight. Yield: $6.41 \mathrm{~g}(71 \%)$. FT-IR (ATR mode) [20,23]: $3566(\mathrm{w})$, $3221(\mathrm{w}), 1635(\mathrm{w}), 1402\left(\mathrm{w}, \mathrm{v}_{(\mathrm{CO} 3) 2}\right), 1086\left(\mathrm{~m}, \mathrm{v}_{(\mathrm{PO} 4) 3-}\right)$, 1014 (s, $\left.v_{(\mathrm{PO} 4) 3-}\right), 960$ (m, $\left.v_{(\mathrm{PO} 4) 3-}\right), 866(\mathrm{w}) \mathrm{cm}^{-1}$. Raman [24]: 429 (w, v $(\mathrm{PO} 4) 3-), 587$ (w, $\left.v_{(\mathrm{PO} 4) 3}\right), 961$ (s, $\left.v_{(\mathrm{PO} 4) 3-}\right), 1044(\mathrm{w}$, $\left.v_{(\mathrm{PO} 4) 3-}\right), 1073\left(\mathrm{w}, v_{(\mathrm{PO} 4) 3-}\right) \mathrm{cm}^{-1}$. XRD: Calcium phosphate hydroxide $\left(\mathrm{Ca}_{5}\left(\mathrm{PO}_{4}\right)_{3} \mathrm{OH}\right.$, monoclinic; ref. card: 76-0694).

\section{Synthesis of monolithic scaffold materials $[6,7]$}

Two solutions, A and B, were prepared and chilled to $0{ }^{\circ} \mathrm{C}$. Solution A consisted of cis-5-cyclooctene-trans-1,2-diol, the $\mathrm{CL}$, the macroporogen (2-propanol) and the inorganic filler $\left(\mathrm{CaCO}_{3}\right.$ and $\mathbf{H A p}$, respectively; 0-12 wt \%). Solution B was obtained by dissolving $\mathrm{RuCl}_{2}(\mathrm{Py})_{2}\left(\mathrm{IMesH}_{2}\right)(\mathrm{CHPh})\left(\mathrm{IMesH}_{2}=\right.$ 1,3-dimesitylimidazolin-2-ylidene, $\mathrm{Py}=$ pyridine; $0.07 \mathrm{wt} \%$ ) in the microporogen (toluene, 9 wt \%). Solutions A and B were mixed and stirred for a few seconds. The polymerization mixture was poured into $1 \times 5 \mathrm{~cm}$ plastic devices. Polymer formation occurred within 12 hours in air. The monoliths were extensively washed with a mixture of $\mathrm{CHCl}_{3}$, DMSO and ethyl vinyl ether $(2: 40: 28 \mathrm{wt} \%)$. Finally, they were washed with $\mathrm{MeOH}$, dried in vacuo and cut into $1 \times 1.5 \mathrm{~cm}$ pieces. A summary of the compositions is given in Table 1 .

\section{Cultivation of adipose tissue-derived stromal cells}

The harvesting and cultivation of human adipose tissue-derived stromal cells (hATSCs) has been previously described $[25,26]$. Briefly, small pieces of subcutaneous adipose tissue $\left(<0.5 \mathrm{~cm}^{3}\right)$ from the lateral thigh region were collected during elective surgery in the Department of Oral and Maxillofacial Surgery of the University of Rostock. The adipose tissue was minced with sterile scissors and subjected to collagenase digestion (collagenase type II, Boehringer, Mannheim, Germany). The suspension was centrifuged (300 g, $10 \mathrm{~min}$ ) and plated in tissue culture flasks (Greiner, Frickenhausen, Germany). Cells were cultured in a $5 \%$ humidified $\mathrm{CO}_{2}$ atmosphere at $37{ }^{\circ} \mathrm{C}$. Culture medium ("standard medium": Iscove's MDM / HAM F12 1:1, supplemented with $10 \%$ neonatal calf serum (NCS), all from Life Technology, Paisley, Scotland) was changed every second day. The stem cell character of these cells has been previously demonstrated by successful osteogenic, adipogenic and smooth muscle differentiation $[6,7,20,27]$. The cells were split in a $1: 4$ ratio and amplified up to the third passage.

Sterilization of the samples was accomplished with $\gamma$-irradiation with the aid of a ${ }^{60} \mathrm{Co}-\gamma$-source at the Leibniz-Institute of
Surface Modification (IOM, Leipzig, Germany) on a rotating table at a dose rate of $0.79 \mathrm{kGy} / \mathrm{h}$. The dose rate was determined by Fricke-dosimetry. The reliability of the dose determination was checked against IAEA-alanine dosimeters resulting in an overall accuracy of the dose measurements of $\pm 5 \%$. The total dose applied was $24 \mathrm{kGy}$.

\section{Cell proliferation assay}

Tests were made in 24-well-plates and 6-well-plates with a well diameter of 2 and $3.5 \mathrm{~cm}$, respectively. Sterile discs of the monolithic test material (1-2 $\mathrm{mm}$ in height) were placed into the wells and covered with standard cell culture medium. After incubation in a humidified atmosphere at $37^{\circ} \mathrm{C}$ for two days, the medium was removed and the discs were seeded. Cultures of third passage hATSC of three individuals were pooled for the experiment and seeded onto the discs at a density of 20,000 cells per $\mathrm{cm}^{2}$. After 1, 2, 4, 8, 12 and 16 days of culture, the discs were harvested and fixed in $4 \mathrm{wt} \%$ formaldehyde in PBS (phophate buffered saline, Serva, Heidelberg, Germany) for 20 minutes. Discs were incubated in 4',6-diamidino-2-phenylindole (DAPI, Sigma-Aldrich, Steinheim, Germany) solution and examined under a fluorescent microscope (Axiovert 25, Zeiss, Jena, Germany). In every specimen, cells were counted in six fields and averaged.

\section{Supporting Information}

\section{Supporting Information File 1}

IR and Raman spectra of HAp and $\mathrm{CaCO}_{3}$.

[http://www.beilstein-journals.org/bjoc/content/

supplementary/1860-5397-6-137-S1.pdf]

\section{Acknowledgements}

This work was supported by the Graduate School of Excellence "BuildMoNa", University of Leipzig, Germany. We wish to thank A. Prager for recording of the SEM and EDX pictures, Dr. M. Lorenz and Dr. W. Fritzsche for support during XRD measurements and Dr. W. Knolle for sterilization of the samples.

\section{References}

1. Puppi, D.; Chiellini, F.; Piras, A. M.; Chiellini, E. Prog. Polym. Sci. 2010, 35, 403-440. doi:10.1016/j.progpolymsci.2010.01.006

2. Marler, J. J.; Upton, J.; Langer, R.; Vacanti, J. P. Adv. Drug Delivery Rev. 1998, 33, 165-182. doi:10.1016/S0169-409X(98)00025-8

3. Nerem, R. M. Ann. Biomed. Eng. 1991, 19, 529-545. doi:10.1007/BF02367396

4. Langer, R.; Vacanti, J. P. Science 1993, 260, 920-926. doi:10.1126/science.8493529 
5. Cortesini, R. Transplant Immunol. 2005, 15, 81-89. doi:10.1016/j.trim.2005.09.013

6. Buchmeiser, M. R. J. Polym. Sci., Part A: Polym. Chem. 2009, 47, 2219-2227. doi:10.1002/pola.23328

7. Löber, A.; Verch, A.; Schlemmer, B.; Höfer, S.; Frerich, B.; Buchmeiser, M. R. Angew. Chem. 2008, 120, 9278-9281. doi:10.1002/ange.200801872

Angew. Chem., Int. Ed. 2008, 47, 9138-9141.

doi:10.1002/anie.200801872.

8. Engler, A. J.; Sen, S.; Sweeney, H. L.; Discher, D. E. Cell 2006, 126, 677-689. doi:10.1016/j.cell.2006.06.044

9. Benoit, D. S. W.; Schwartz, M. P.; Durney, A. R.; Anseth, A. S. Nat. Mater. 2008, 7, 816-823. doi:10.1038/nmat2269

10. Lenhert, S.; Meier, M.-B.; Meyer, U.; Chi, L.; Wiesmann, H. P. Biomaterials 2005, 26, 563-570. doi:10.1016/j.biomaterials.2004.02.068

11. Liao, H.; Andersson, A.-S.; Sutherland, D.; Petronis, S.; Kasemo, B.; Thomsen, P. Biomaterials 2003, 24, 649-654. doi:10.1016/S0142-9612(02)00379-4

12. Gray, C. Tissue Eng. 1998, 4, 315-323. doi:10.1089/ten.1998.4.315

13. Weiner, S.; Wagner, H. D. Annu. Rev. Mater. Sci. 1998, 28, 271-298. doi:10.1146/annurev.matsci.28.1.271

14. Dorozhkin, S. V.; Epple, M. Angew. Chem., Int. Ed. 2002, 41 , 3130-3146. doi:10.1002/1521-3773(20020902)41:17<3130::AID-ANIE3130>3.0.CO ;2-1

15. Du, C.; Cui, F. Z.; Zhu, X. D.; de Groot, K. J. Biomed. Mater. Res. 1999, 44, 407-415. doi:10.1002/(SICI)1097-4636(19990315)44:4<407::AID-JBM6>3.0.CO; 2-T

16. Bandari, R.; Knolle, W.; Buchmeiser, M. R. J. Chromatogr., A 2008, 1191, 268-273. doi:10.1016/j.chroma.2007.11.016

17. Schlemmer, B.; Gatschelhofer, C.; Pieber, T. R.; Sinner, F. M.; Buchmeiser, M. R. J. Chromatogr., A 2006, 1132, 124-131. doi:10.1016/j.chroma.2006.07.058

18. Buchmeiser, M. R. Bioorg. Med. Chem. Lett. 2002, 12, 1837-1840. doi:10.1016/S0960-894X(02)00275-5

19. Krenkova, J.; Lacher, N. A.; Svec, F. Anal. Chem. 2010, 82, 8335-8341. doi:10.1021/ac1018815

20. Weichelt, F.; Frerich, B.; Lenz, S.; Tiede, S.; Buchmeiser, M. R. Macromol. Rapid Commun. 2010, 31, 1540-1545. doi:10.1002/marc.201000317

21. Bandari, R.; Prager-Duschke, A.; Kühnel, C.; Decker, U.; Schlemmer, B.; Buchmeiser, M. R. Macromolecules 2006, 39, 5222-5229. doi:10.1021/ma0609883

22. Wang, A.; Liu, D.; Yin, H.; Wu, H.; Wada, Y.; Ren, M.; Jiang, T.; Cheng, X.; Xu, Y. Mater. Sci. Eng., C 2007, 27, 865-869. doi:10.1016/j.msec.2006.10.001

23. Okada, M.; Furuzono, T. J. Nanopart. Res. 2007, 9, 807-815. doi:10.1007/s11051-006-9126-1

24. Silva, C. C.; Sombra, A. S. B. J. Phys. Chem. Solids 2004, 65, 1031-1033. doi:10.1016/j.jpcs.2003.10.071

25. Frerich, B.; Kurtz-Hoffmann, J.; Lindemann, N.; Müller, S. Mund Kiefer GesichtsChir. 2000, 4 (Suppl. 2), S490-S495.

26. Frerich, B.; Lindemann, N.; Kurtz-Hoffmann, J.; Oertel, K. Int. J. Oral Maxillofac. Surg. 2001, 30, 414-420. doi:10.1054/ijom.2001.0130

27. Weinzierl, K.; Hemprich, A.; Frerich, B. J. Cranio-Maxillofac. Surg. 2006, 34, 466-471. doi:10.1016/j.jcms.2006.07.860

\section{License and Terms}

This is an Open Access article under the terms of the Creative Commons Attribution License

(http://creativecommons.org/licenses/by/2.0), which permits unrestricted use, distribution, and reproduction in any medium, provided the original work is properly cited.

The license is subject to the Beilstein Journal of Organic Chemistry terms and conditions:

(http://www.beilstein-journals.org/bjoc)

The definitive version of this article is the electronic one which can be found at:

doi:10.3762/bjoc. 6.137 